\title{
Erratum to: Hydrogeological investigation of groundwater artificial recharge by treated wastewater in semi-arid regions: Korba aquifer (Cap-Bon Tunisia)
}

\author{
Hassen Ouelhazi • Fethi Lachaal • Abdelkrim Charef • \\ Bilel Challouf • Habib Chaieb
}

Published online: 2 March 2014

(C) Saudi Society for Geosciences 2014

Erratum to: Arab J Geosci (2013)

DOI 10.1007/s12517-013-1090-3

At the request of Dr. Faten Jarraya Horriche and by mutual agreement between the Authors and the Editor the name of Dr. Faten Jarraya Horriche should be removed from the author list as the manuscript was submitted without her knowledge. Dr. Faten Jarraya Horriche has not contributed to the conception and design, acquisition, analysis and interpretation of data, nor was he involved in drafting the article or revising it.

The online version of the original article can be found at http://dx.doi.org/ 10.1007/s12517-013-1090-3.

H. Ouelhazi $\cdot$ F. Lachaal $(\bowtie) \cdot$ A. Charef $\cdot$ B. Challouf

Georesources Laboratory, Water Research and Technology Centre, Tunisia, Borj Cedria Ecopark, PO Box 273, Soliman 8020, Tunisia e-mail: lachaalfethi@yahoo.fr

F. Lachaal

e-mail: fethi.lachaal@certe.rnrt.tn

H. Chaieb

General Direction of Water Resources, Ministry of Agriculture in

Tunisia, 43, rue Saida El-Manoubia, Monfleury 1008 Tunis, Tunisia 